Old Title, New Traditions : Negotiating Ideals of Femininity in Krest'ianka Magazine

\title{
Ratilainen, Saara
}

$2014-12-20$

Ratilainen , S 2014 , ' Old Title, New Traditions : Negotiating Ideals of Femininity in Krest'ianka Magazine ' , Feminist Media Studies , vol. 15 , no. 1 , pp. 92-112 . https://doi.org/10.1080/14680777.201

http://hdl.handle.net/10138/305473

https://doi.org/10.1080/14680777.2015.988394

cc_by_nd

acceptedVersion

Downloaded from Helda, University of Helsinki institutional repository.

This is an electronic reprint of the original article.

This reprint may differ from the original in pagination and typographic detail.

Please cite the original version. 
Published in Feminist Media Studies 15:1, 92-112

DOI: $10.1080 / 14680777.2015 .988394$

Old Title, New Traditions: Negotiating Ideals of Femininity in Krest'ianka Magazine

\begin{abstract}
:
This article examines Krest'ianka magazine, a former Soviet women's publication, which has been transformed into a post-Soviet glossy magazine. The analysis explores how the Soviet past is used in the magazine as a discursive tool for articulating ideals for postSoviet femininity. Furthermore, the article discusses how the magazine negotiates the neo-traditional gender ideology of twenty-first century Russia with the legacies of the Soviet period. Drawing on Maija Töyry's idea that women's magazines communicate existing social norms and values through "negotiable relations," the article addresses the representations of three central themes found in issues of Krest'ianka published between 2000 and the present. These themes include, gender differences, cultural nostalgia, and consumption, and they form the contours of the "new" Russian woman which emerges from the pages of the pages of this magazine.
\end{abstract}

Keywords: glossy magazines, post-Soviet Russia, femininity, gender representations, nostalgia, consumption

\title{
Introduction
}


Most consumer magazines that we read today, both in the East and in the West, are printed on beautiful glossy paper. In this format, the magazine is expected not only to look appealing to the buyer's eye, but to have an "aura of exclusivity" that helps to construct a certain image of the magazine's desired reader as the "ideal consumer" (Gough-Yates 2003, 82, 125-126). Glossy paper started to function as the marker of consumerist print media almost simultaneously in Eastern and Western Europe. In the latter, this happened in the 1980s and 1990s, and in Eastern Europe, in the 1990s. Today, the post-Soviet publication market offers a vast potential for economic success, especially for large international glossy magazine publishers (Vartanova and Smirnov 2010). Furthermore, in contemporary Russia, glossy lifestyle magazines (gliantsevye zhurnaly) have attained cultural meanings that can be fully understood only when interpreted in relation to their post-socialist context. For example, as a result of the fundamental socioeconomic change ushered in by desovietization, the (re)organization of the media market brought several popular genres into the cultural center. Among these was the glossy consumer magazine, which has come to represent the rise of a capitalist system of values, especially an individual's freedom to consume and to choose her or his lifestyle, profession, and hobbies (Goscilo 2000b).

The first Russian glossy magazine, Domovoi (House Spirit), ${ }^{1}$ was introduced in 1993 as a general-interest magazine targeting women, and was originally published by the Kommersant Publishing House. A Russian edition of the Western magazine brand Cosmopolitan, currently the most popular women's magazine in Russia, appeared in 1994 and was followed in 1995 by the a Russian edition of the men's magazine Playboy. By the end of the decade, a number of domestic and international glossy magazines were 
on the market, aimed at audiences of different age groups and social strata (Bartlett 2006; Goscilo 2000b; Gudova \& Rakipova 2012; Litovskaia 2008). Since the beginning of the twenty-first century, the Russian glossy magazine market has continued to evolve, becoming even more segmented. For example, in 2011, almost 10,000 titles were published, with a total circulation of 900 million (Vartanova and Smirnov 2010, 22). Once recognized as something that inherently belongs to Russia's new, post-socialist media system, the glossy magazine also started to function as a lens through which postSoviet cultural development can be scrutinized, interpreted, and experienced. For instance, Birgit Menzel $(2008,5)$ has argued that the market success of Russian glossy magazines represents a change "from a society of distributors to one of consumers, from a text-oriented culture to image-oriented culture" (see also Goscilo 2000b; Gudova \& Rakipova 2012, 45).

In addition, the glossy magazine represents a drastic transformation in the magazine format that was dominant in Soviet Russia. Former Soviet high-circulation, "thin" popular magazines, which were produced for "the masses" — such as Za Rulem (Behind the Wheel), Zdorov'ie (Health), Rabotnitsa (Working Woman) and Krest'ianka (Peasant Woman) — have all adopted a thicker and glossier format. Moreover, the loss in readership of "thick" literary magazines, which enjoyed high cultural status in Soviet times, is often contrasted with the rise of the glossy consumer magazine market (Berg 2002, 7; Goscilo 1999, 7; Lovell 2000; Menzel 2005). The glossy consumer magazine has thus emerged as a defining factor of post-Soviet Russian reading culture because it creates a discursive framework in which two major trajectories - the disintegration of 
Soviet literary institutions and the diversification of post-Soviet commercial mass media — connect and intertwine.

Against this background, this article investigates how the Russian women's magazine Krest'ianka renegotiates femininity and gender norms in post-Soviet society. Krest'ianka is one of the few originally Soviet titles that are still published in Russia today. Therefore, examining Krest'ianka opens up an interesting perspective on the ways in which a traditional Soviet women's magazine has reinvented itself as a post-Soviet glossy publication. My analysis of how Krest'ianka portrays post-Soviet femininity in the context of the history of gender relations identifies three seminal discursive frameworks: gender differences, cultural nostalgia, and consumption. I argue that Krest'ianka uses the Soviet past as a powerful discursive tool for constructing ideals for post-Soviet femininity, and does so in order to negotiate between neo-traditional gender ideology and rising consumerism in twenty-first century Russia. Ultimately, I maintain that Krest'ianka's ideal reader represents the "new" Russian woman who embraces consumerist and at the same time traditionalist values.

\section{Data and Methodology}

The data examined for this study consists of the issues of Krest'ianka from January 2000 through January 2014. My analysis focuses specifically on two kinds of editorial content: readers' and experts' opinions published as part of Krest'ianka's monthly sections Tema nomera (Theme of the month), and lengthy, illustrated, feature articles about domestic celebrities. ${ }^{2}$ Most of the feature articles appeared under the rubrics Semeinye istorii (Family stories) or Semeiaia povest' (Family saga) (until August 2008), and Privat - moda (Private - fashion) from January 2002 until August 2008. In 
October 2008, Krest'ianka changed its concept and stopped including these rubrics; however, stories about domestic celebrities, discussing their family lives and style, remain a central part of the magazine to this day. "Family Stories" typically portray famous Russian couples, simultaneously presenting a narrative of professional success that emphasizes serious devotion and distinguished individual skills as a pathway to both familial happiness and a socially privileged lifestyle. In the series "Private Fashion" Russian celebrity women reveal the secrets of their style and combine their opinions on the latest trends with stories about their professional and personal lives. These sections were chosen for analysis because they actively participate in the (de)construction of Krest'ianka's ideal reader by defining and redefining Russian women's professional, family, and consumer identities, thereby highlighting the negotiation of gender and femininity in post-socialist Russia.

The ideal reader is an abstraction of the magazine's target audience conveyed through a combination of different story types and other contents, such as advertisements, fashion pages, and interviews. Some magazine brands are based on a strongly individualized ideal reader who appears as the "protagonist" of every issue, such as the “Cosmo girl” from Cosmopolitan (Winship 1987, 99-122). Anna Gough-Yates (2003, 125) points out that women's magazine editors function as cultural intermediaries who create the image of the publication's ideal reader, usually by marrying the image of a fashion-conscious consumer to professional success stories. In these types of representations, certain products, labels, and consumption patterns become markers of professional success and, ultimately, of upward class mobility. 
My reading of the research material draws on Foucault's theory of discourse. Discourses, according to Foucault, are formed out of statements that are reproduced, transformed, and used for manipulating the enunciative field in which they occur. Therefore more important than analyzing the possible meanings of statements is determining what are the factors and circumstances that have made the occurrence of a certain statement possible, i.e., "how is it that one particular statement appeared rather than another?" (Foucault 1972, 27). The popular media in post-Soviet Russia are an important tool for the circulation and multiplication of gender representations. At the same time, the cultural and historical contexts of these representations also inform the ways in which they construct an ideal reader, as each media image is based on some shared notions of cultural, aesthetic, and ethical boundaries.

\section{Gender Relations in Soviet and Post-Soviet Russia}

The Soviet gender system left an ambiguous legacy in post-Soviet Russia. The neglect of women's bona fide needs by the Soviet state and the strict top-down character of the Soviet women's movement can now be seen as forming the foundation for commonly held negative attitudes towards feminism in post-Soviet Russia. The prevailing opinion is that Soviet (over)emancipation failed as it exhausted women with a double burden and "emasculated" men (Hemment 2007, 5). Therefore, after the collapse of the Soviet system, the revival of traditional gender ideals, which associate femininity with domesticity and motherhood, and masculinity with the public sphere and power, has been hailed enthusiastically by many post-Soviet citizens, regardless of gender.

Although feminist thought took root in post-Soviet Russia in the 1990s, resulting, for instance, in the establishment of several academic centers for gender studies and civic 
women's organizations, both domestic and international institutional support for feminism has decreased since the beginning of the twenty-first century (Hemment 2007; Salmenniemi 2014). At the same time, after the 1990s sexualization of culture and "porn boom," post-Soviet popular culture has cemented into the mainstream representations of the objectified and commodified female body as part of the public domain (Borenstein 2008; Goscilo 1996; Goscilo 2000a, 10-11). Furthermore, decreased birth rates and the increased influence of the Russian Orthodox Church on the Kremlin have strengthened the neo-traditional and neo-conservative orientation of Russian public discourse in the 2000s (Rosenholm and Savkina 2010; see also Rivkin-Fish 2006; Rotkirch, Temkina, and Zdravomyslova 2007).

Recent scholarship has identified post-feminist gender representations in postSoviet commercial media (Gudova and Rakipova 2010, 61-66; Salmenniemi and Adamson 2014). ${ }^{3}$ Women's popular genres such as glossy magazines, self-help literature, chick lit, and makeover programs have played a significant role in the development of post-feminist media culture in the West. Through globalized media structures, their influence has spread across national and cultural boundaries. For example, Salmenniemi and Adamson (2014) argue that the cultural domestication of neoliberal capitalism and popular psychology discourses function symbiotically in the formation of post-feminist identities in contemporary Russia. Gudova and Rakipova $(2010,64)$ point out that popular magazines based on Western formats have “modernized” Russian women's thinking according to post-feminist ideology.

Drawing on these ideas of Russian gender ideology and media culture, this article contributes to the expanding field of post-Soviet women's magazine studies and the study 
of women's popular culture. The emergence of the international consumer magazine industry in post-Soviet Russia (dis)placed the original concept of Krest'ianka that was central for the Soviet mass media system. The magazine entered the new international context of glamour and celebrity (see Goscilo and Strukov 2011). Therefore, examining how Krest'ianka creates a post-Soviet brand as a glossy consumer magazine by accenting domestic female celebrities as objects of idolization and emulation advances our understanding of the ways in which gender is redefined in through globalized media formats.

My discussion begins with a description of Krest'ianka's history and its major conceptual changes. It then proceeds to analyze the representation of gender difference and the essentialist discourse of Krest'ianka in the 2000s. The following section examines how Krest'ianka's essentialist ideas of gender intertwine with cultural nostalgia, before moving to a consideration of the role played by consumerism in Krest'ianka's portrayal of post-Soviet femininity.

\section{Krest'ianka in the Soviet and Post-Soviet Periods}

Krest'ianka began publishing in 1922, in the aftermath of the Bolshevik Revolution, and together with Rabotnitsa (Working Woman), which was launched in 1914, they were the only Soviet women's magazines aimed at a mass readership. The titles of these two magazines expressed a division into two categories of the Soviet female audience: Rabotnitsa targeted urban factory workers, whereas Krest'ianka addressed kolkhoznitsy — women working at Soviet state farms, kolkhozy (Attwood 1999, 25-26; Gudova and Rakipova 2012, 13). 
These magazines played a twofold role in the Soviet Union. First, they functioned as mouthpieces of the Central Communist Party, offering a special venue for the promotion of official Soviet ideas about women's emancipation. Therefore they played a significant role in the political and ideological education of the Soviet population. Second, women's mass magazines performed the difficult task of developing and maintaining Soviet consumer culture; they were one of the few forms of mass media that repeatedly discussed home decoration, style, and beautification. Especially during the late Soviet period, Krest'ianka and Rabotnitsa actively promoted "Soviet chic" — fashion that was based on the socialist virtues of functionality and modesty (Gudova and Rakipova 2012). During perestroika, Krest'ianka underwent a strong discursive turn, and began to articulate many formerly silenced issues, such as Stalin's terror and the grim realities of Soviet everyday life, opening them up for discussion. The overall changes in late Soviet society and mass media created a background against which the "peasant woman" as the main heroine and ideal reader of Krest'ianka began to undergo a process of deconstruction, though even in the late 1980s the magazine featured mainly an agrarian lifestyle (see Figure 1).

[Insert Figure 1 here.]

Following the collapse of the Soviet Union, Krest'ianka struggled for survival in the new market. Without the economic resources that the Soviet planned economy had steadily guaranteed, Krest'ianka had to adjust to the competitive media market, its circulation dropping from over 20 million copies to several hundred thousands (Goscilo 
2000b, 25). Furthermore, Goscilo notes that the 1990s witnessed visual, stylistic, and editorial experiments by a number of new domestic lifestyle magazines, international competitors were setting new standards for quality, the country's economy drifted from one crisis to another, and Russian popular culture was obsessed with reproducing Western representations of opulent style as the most important signifiers of the postSoviet good life (25).

Since 2005 Krest'ianka has been owned by one of the largest Russian media enterprises, Rodionov Publishing House, which also publishes other glossy magazines intended for different readerships, including the previously mentioned Domovoi, as well as men's magazines $X X L$ and FHM. Among these publications, Krest'ianka has the largest circulation and is the only one carrying an original Soviet title. The readership of post-Soviet Krest'ianka's comprises urban, middle-aged, and middle- or upper-middleclass women. During the 2000s its circulation has fluctuated between approximately 150,000 and 180,000 copies. One of the five most popular women's glossy magazines in Russia, it reaches most of its readers outside the largest economic centers of Moscow and St. Petersburg, namely in the Ural region, in Siberia, and in Southern Russia (Gudova and Rakipova 2012, 18). Gudova and Rakipova also describe its audience as "loyal" and “interactive," which is proven by the 100 or so readers' letters from all over the country the editors receive daily. During the 2000s, Krest'ianka's head editor changed six times, which also caused shifts in the magazine's visual and editorial style.

Given the dynamic, consumer-driven media market of post-Soviet Russia, Krest'ianka actively refers to its Soviet history both as a means of self-identification as an authentic Russian version of the glossy magazine, and as a means of differentiation 
from competitors on the market. Although the contemporary Krest'ianka follows the international trend of fashion magazines by using studio shoots of models and celebrities as cover illustrations, the reproduction of old Soviet covers and articles in special sections has been a continuing practice until recently. For example, from September 2008 through October 2009, in one of several redesigns during the post-Soviet years, the magazine's covers ran a series of photographs in the style of Soviet magazine covers and propaganda posters (see Figure 2).

[Insert Figure 2 here.]

\section{Krest’ianka Discussing Gender Difference}

In the January issue 2014, actress Anastasiia Mel'nikova states in a short interview that "a woman should be soft and weak" (Mel'nikova 2014, 8). ${ }^{4}$ Mel'nikova remembers her mother as a successful doctor who "worked her entire life" while having full responsibility for the house and family. She notes that it was impossible even to imagine a man washing dishes or doing laundry in their house (8). Seemingly unaware of her self-contradiction, Mel'nikova equates "soft and weak" femininity with her mother, the Soviet working woman, who seems far from weak — on the contrary, she appears to have been the prototype of the overburdened Soviet "emancipated woman." Mel'nikova's opinion, however, is a typical instance of Krest'ianka's representation of femininity in the new millennium, which simultaneously praises and diminishes the well-known image from the past. Positing sensitivity and sensuality as key markers of post-Soviet femininity deconstructs the image of the "Soviet emancipated woman" by emphasizing the physical differences between the sexes - a tendency that I analyze in more detail below. ${ }^{5}$ 
A section titled Vlast' $i$ zhenshchina (Power and Woman) in the August 2006 issue of Krest'ianka illuminates the overall logic according to which gender relations and women's social roles are often portrayed in the magazine during the early 2000s. The debate under this rubric offers a good example of the widespread tendency in women's magazines to discuss topics through contradictions, oppositions, and "negotiable relations" (Töyry 2005, 93-100). ${ }^{6}$ Suggesting that it is possible to celebrate Russian women in leading positions, this discussion introduces the "career-oriented business woman" as the most representative image of a woman in a leading position. Yet the debate is based on a strongly essentialist discourse, which relies on the idea of underlying, primordial gender relations, expressed through such phrases as "masculine" and "feminine" "traits" (cherty), "foundation" (nachalo), and "nature" (natura).

This discourse is developed in two steps. First, the post-Soviet woman is represented as having a relationship with power that requires closer examination. This is exemplified by such questions as: "Can a woman be given power?" "Can a woman in a leading position stay soft and sweet?" and "What did emancipation bring to us?" (Krest'ianka 2006, 9, 12). Secondly, answers to these questions for the most part pose problems that allegedly emerge when a woman steps into a powerful position. In some cases, the difficulties are related to combining a demanding job with a family, but the prevailing concern is whether a woman's "nature" is suitable for a leading position. The argumentation draws from a binary-oppositional and mutually exclusive model of gender polarities, which defines the "natural traits" of men and women, and suggests that these gender characteristics are what should define people's roles both at work and in the family. 
Judging from the published selection of readers' and celebrities' opinions, Krest'ianka presents neither a positive nor a negative attitude toward women's leadership. Highly negative and very positive comments, published side by side, are based on similar arguments about both genders' supposedly inherent inclinations and the impact of these inclinations on the professional skills needed for leadership. For instance, female leaders supposedly differ from males owing to their emotional characters, good organizational skills, and their particular interest in people and relationships. Viewing management of the family as a "natural" feminine task, readers judge women's leadership as a positive phenomenon in the discursive framework of social motherhood (see Winship 1987, 32-35). Roza Siabitova, owner of a dating agency, defines "feminine" business as being the only legitimate area of women's leadership because "[b]y nature, women tend to avoid risks and preserve and multiply what is achieved and created by men" (Krest'ianka 2006, 9). Also, plastic surgeon Aleksander Tepliashin explains the value of a female leader in the following terms:

[A female leader] tends toward noble acts; she takes a conciliatory approach to controversies and makes soft decisions. A woman is never bloodthirsty or obsessed with crazy ideas that can bring misfortune to entire nations. (...) Criminal regimes arise as a result of only man's work; women are not capable of coldblooded murder. (...) They are caring and thoughtful, more apt to have mercy than execute. They try to strengthen family values. (10) According to these opinions, the business world is divided into masculine and feminine sectors, which operate separately but exist in a hierarchical relationship, paralleled to the private family setting and public world of government and finance. This 
basic division between masculine and feminine spheres is explained on a more "theoretical" level in an interview with psychologist Aleksei Akimov, which purports to place the discussion in a philosophical and historical context. Introduced as Krest'ianka's "regular consultant" $(2006,12)$, Akimov represents a voice of trusted authority whose professional statement seals the preceding exchange of opinions. The psychologist notes that Russia is experiencing a transitional period, during which women are acquiring "masculine" traits and therefore actively pursuing professional careers, property, and power. He explains that in this process women have lost their "natural" contribution to society, which entails their being flexible and guided by other people's opinions.

It is interesting to note that here gender identities are conceptualized in terms derived from feminist studies (such as patriarchy, matriarchy, emancipation, and gender equality), although the overall take on the issue is strongly essentialist. In addition, the psychologist applies the post-feminist popular psychological discourse that became widespread in Russia in the late 1990s and early 2000s by calling career-oriented women "shrews" (stervy) (see Salmenniemi and Adamson 2014). According to him, this is not an insult but a psychological description of a phase in women's evolution. During this phase, women abandon their motherly principles and strive for the things that have traditionally been possessed by men: careers in business and politics. He also defines feminism as women's rivalry with men, concluding that "a wise woman does not fight men but always finds a way to make the man even stronger by setting him ahead, by inspiring him to acts of heroism, and by supporting him in hard moments." With this approach to gender differences, the psychologist maintains, a woman will reach the highest level of womanhood, becoming a "priestess" (zhritsa) (Krest'ianka 2006, 12-13). 
According to Akimov, the priestess is also the "great mother" (13). In fact, the representation of woman as mother tends to overwhelm the multitude of articles about successful professional women published in each issue of Krest'ianka. ${ }^{7}$ Such "family stories," as I have argued elsewhere (Ratilainen 2010), create a narrative framework enabling the discursive transformation of a successful professional woman into the archetypal Russian mother figure. Furthermore, the neo-traditional gender ideology put forward by these stories supports the image of the post-Soviet patriarchal family and legitimizes its symbolic use.

Some "Family Stories" especially stress the process of female transformation by using a semantic pattern that Victor Stoichita $(2008,182)$ calls the "Pygmalionian relationship.” For example, a story from February 2004 titled, “Khudozhestvennyi domostroi" ("Artistic Patriarchy"), represents the family of the sculptor Evgenii Evgenievich Lansere (Shokhina 2004b). The husband is a member of a famous family of artists and therefore his young wife, Alla, has to be educated into her roles of wife and mother to fit his longstanding family traditions. In addition, she also requires professional reeducation - from that of an economist to an art historian.

In another type of Pygmalion relationship presented in the section "Family Stories," the principle of transformative action not only structures men's conjugal relations but also organizes their relationship to their families and encompasses their work and, ideally, all of Russia. For example, in a story about the famous spousal duo Nadezhda and Aleksandr Kostiuk, the husband Aleksandr describes how the couple got married and had a child only upon his "strong-willed decision." Aleksandr performs the role of "father the creator" also in the professional field, for he composes the music 
performed by his wife. On top of this, he has reconstructed an old film theater in Moscow into a National Theater of Folk Music, Zolotoe Kol'tso (The Golden Ring), where, as Aleksandr describes in the interview, "Russian national ensembles, who are currently popular only in the West, are given the opportunity to reach fans in the homeland" (Denisova 2005, 17). In this way, the husband is portrayed "as the original source and driving force of both their family life and professional careers” (Ratilainen 2010, 170), which ultimately works for the benefit of Russian culture and society.

In these images of Russian celebrity families, "the husband represents a fixed image" (Ratilainen 2010, 169). He is sanctioned by family tradition, his profession, and his skills, while the wife remains as material that is "pliable" and "responsive" (Gubar 1985, 292) — like the marble out of which Pygmalion carves his statue of an ideal woman. According to Gubar (1985), Pygmalion's statue symbolizes the male artist's Other (i.e., creation-companion,) through which he attempts to deny that he himself is "created out and from the female body" (292).

A similar type of denial of women's life-creating power also marks Krest'ianka's "Family Stories." In several of them (e.g., see Shokhina 2001, 8-10; 2004a, 6-11; 2004c, $8-13 ; 2005,1-15)$, even the significance of the mother as responsible for reproduction is denied by binding together the concepts of creating a family, building a career, and commitment to social improvement, which are all seen as materialized in the father of the family. In other words, the father becomes the ultimate source in whose hands lies even the woman's maternal capacity. Such extremely patriarchal family representations, illustrate how Krest'ianka's gender discourse naturalizes culturally and socially 
problematic messages, deeply connected to the neo-traditional ideology of post-Soviet society as though they were "meant to be" (see also Ratilainen 2010).

\section{Nostalgia and Krest'ianka's Eternal Femininity}

Many stories in Krest'ianka's subscribe to ahistorical, essentialist conceptions of gender that are cast as immutable. Yet they simultaneously tend to regard Russia's social transformation as having altered dominant expressions of masculinity and femininity. This tension between immutability and transformation in representations of femininity can be analyzed further through the framework of cultural nostalgia, which connects the symbolic understanding of Russian womanhood as an important part of "national pride" to Krest'ianka's identity as a heritage magazine brand.

A term of Greek origin, nostalgia translates in Russian as "the pain of returning home" or "homesickness as mental disorder" (Dal'1994, 1442). Besides longing for a return to a certain place or time, nostalgia expresses the loss of something good, beloved, and close to one's heart. A number of scholars have discussed nostalgia as a predominant post-Soviet discourse, which draws its importance from the feeling of lost stability and the "acute dislocation" (Cassiday and Johnson 2013, 50) of the Russian collective identity. As Svetlana Boym points out: "The revolutionary époque of perestroika and the end of the Soviet Union produced an image of the last Soviet decades as (...) a Soviet golden age of stability, strength, and 'normalcy"' (2001, xvi). Therefore, nostalgia can also be understood as a persistent state of memorializing — recalling and embellishing the past through various symbolic practices.

The ambiguous practices of cultural nostalgia can also be interpreted as a response to the political situation in Russia at the beginning of the twenty-first century, 
when the economic stabilization and centralization of power began. Lev Gudkov characterizes post-Soviet nostalgia as the "idealized stability of prosperity" $(2004,659-$ 660). Serguei Oushakine connects nostalgic representations to a reestablished sense of a cultural continuum between Soviet and post-Soviet periods:

Attempts to clearly differentiate "victims" and "villains" of the Soviet regime were increasingly replaced by conscious efforts to restore the lost feeling of collective belonging and to reestablish cultural connection with the past that would be neither horrifying nor humiliating. (2007, 452)

Active adoption of the discourse of cultural nostalgia thus allows one to identify with authoritarian regimes and power structures, and to envision them as friends, not as "fiends," from the past in a way that would help remodel social organization and identitybuilding in the present. Consequently, post-Soviet nostalgia offers a discursive framework for a multitude of heterogeneous representations, ranging from those longing for Soviet imperial grandeur to others invoking the mythology of prerevolutionary Russia, and in this way nurturing the feelings of cultural coherence, national pride, and even patriotism (Cassiday and Johnson 2013; see also Morris 2005).

Using both texts and images, Krest'ianka avidly embraces this nostalgic discourse. In search of new objects of identification and new discursive connections to its old title, Krest'ianka discusses the main characteristics of the supposed quintessentially Russian woman as an alternative to a Westernized female type. The October issue 2004, dedicated to the theme of "sexual revolution," tackles this question. The introductory article of the issue proclaims: 
The great October Revolution was the first revolution in history as a result of which not only the political order changed, but also the interrelationship between the sexes was reconstructed, i.e. those relationships that lie at the very heart of any social order and that are more ancient than any state, class, or even nation. (Latsis 2004, 14)

The issue points out that the 1917 October Revolution was followed by a sexual revolution - one that has taken a new turn or resurfaced as one of the most important developments in the post-Soviet era. A section running several pages long, comprising readers' letters, editorial articles, and various illustrations, including images of hippie couples, debates the pros and cons of post-Soviet sexual liberation.

The discussion also seeks a modern feminine persona that could function as the heroine of this sexual revolution. One of the readers' letters suggests, for example, that this figure could be Carrie Bradshaw from the television show Sex and the City: "a woman who understands that it is impossible to find the right partner at first try" (Krest'ianka 2004, 18). In the same spirit, another letter suggests that the real heroine of the post-Soviet sexual revolution is "not a real woman of flesh and blood, but an image; a girl from a billboard or a glossy magazine cover" (18). The idea that the typical heroine of the post-Soviet sexual revolution should not be a flesh-and-blood human is reinforced in an editor's note explaining that the images of female bodies in advertisements and glossy magazines are often "distasteful" and "simply offensive towards women" (20). Apparently, Krest'ianka seeks to offer radically different types of feminine role models, which would better fit its brand as a heritage title. 
Tellingly, the overall liberalization of values in post-Soviet Russia is viewed critically in the pages of Krest'ianka. Sometimes the criticism is not overt but expressed through a denial of the contemporary situation and an orientation to the world order that is explained with images from the distant past. The title Krest'ianka, for example, as discussed in its historical framework, refers not only to the Soviet Union and kolkhoznitsy (the kolkhoz women), but also to the more distant history of "Christian Russia," which is seen as having been lost in the aftermath of the October Revolution. In other words, this title acquires a certain meaning of both "the olden days" and the patriarchal gender order inseparable from "eternal" Christian values. For instance, in the January issue of 2006, writer Andrei Bitov defines the meaning of the word "krest'ianka" as follows:

First of all, Krest'ianka is a wonderful brand. [...]. At the same time, this word captures the disarming gentleness of a woman who is one with nature and lives according to God's order. [...] And yet, listen, krest'ianin - krest - khristianin [peasant - cross - Christian], or derevnia - derevo - drevnost' [village - tree eternity]. $(2006,7)$

In the opinion of Bitov, a 77-year-old writer, krest'ianka acquires its meaning through an idealized Christian and agrarian culture. Accordingly, the peasant woman also becomes a symbol of a religious, "natural" woman who lives under a patriarchal regime to which the writer refers as "God's order." This idea of Russian womanhood is far removed from the common portrayal of women presented as the heroines of contemporary glossy magazines. Perhaps Bitov's words attempt to encapsulate the preferred inner qualities of a contemporary Russian woman, but his perspective certainly illustrates "retro- 
orientation" at work. This discourse of Russian femininity draws on an idealized image of the distant past rather than on depicting the present or future (Gudkov 2004, 658).

Lev Gudkov describes retro-orientation as the active use of language and symbols from the past that emphasize the role of the Soviet and Russian imperial great powers as an important national legacy and source of national identity today. He observes that this discourses is a reaction to the general feeling of disappointment shared by many after perestroika and the 1990s reformist politics, which were perceived as having led Russia into chaos. However, as Gudkov argues, the retro-orientation of Russian public discourse at the turn of the twenty-first century was not only a means of building national identity or criticizing social instability, but was also a discursive denial of the democratization and diversification of Russian society on a more general level (Gudkov 2004, 650-662). An example of this type of discourse is a passage from a reader's letter that was published in Krest'ianka in March 2007. The theme of this issue was "Honoring our native country." On the pages of this issue, the texts were accompanied by photographs of the most powerful symbols of Russia and the Soviet Union as superpowers: twoheaded eagles, soldiers, and Soviet monuments. These and many other "symbols from the past" were catalogued in one reader's letter:

If one has to perform the very simple procedure of trying to dredge up from one's memory the symbols of past eras, then images of the Victory Day chronicle, Yuri Gagarin's smile, the statue of the Worker and the Kolkhoz Woman at the Exhibition of National Economic Achievements, Irina Rodnina at the rostrum (and so on) emerge quickly. If we dig deeper, [then we get the] two-headed eagle, golden cupolas, Peter the Great vanquishing the Swedes near Poltava, Alexander 
the First riding to Paris on a white horse, the inspired faces of Moguchaia kuchka [The Mighty Five], images of the peredvizhniki [wanderers], Dostoevsky, Chekhov, Stanislavsky, Russian seasons in Paris. (Krest'ianka 2007, 16)

This passage introduces an overlong list of the images and names that can be regarded as national treasures from Soviet and Russian imperial times. This view of the past offers a well-stocked yet not very orderly storehouse of images and associations in a similar vein as the term krest'ianka does for Bitov in the example above. The author of the letter refers to these "symbols of past eras" as factors that help him or her perceive the Russian nation as a whole. The list of symbols remains on the level of free association, as though the speaker lacked either the perspective or motivation for a more accurate understanding of the history and ideologies represented by the cited names, events, and symbols. At the same time, symbols of national pride that would be connected to the post-Soviet period are conspicuously absent from this list. Addressing the historical past in this way emphasizes the feeling that post-Soviet Russian national pride has not lost its central symbols, but that the symbolic order, the structure that would lend coherence to the discourse of national pride as a viable entity today, has withered away (see Oushakine 2007). Accordingly, the idea of "honoring one's country" is related only to the past, and, indeed, the letter is accompanied by an illustration that depicts the contemporary moment as ruins - the half-destroyed statue of the Worker and the Kolkhoz Woman that the letter also mentions as one of the symbols of past eras (see also Ratilainen 2008b).

\section{Consumption and Feminine Style in the Past and Present}

The understanding of Russian womanhood, in the context of a national history that is best represented through the images of ruined monuments (see Platt 2009), 
becomes renegotiated in Krest'ianka and supposedly even "rebuilt" through the discourse of style, beauty, and everyday consumption. Gudova and Rakipova $(2012,44)$ point out that glossy magazines represent women's everyday life as it would be in its "perfected" form, especially when relying on images of glamorous consumption. Alternatively, the glamorous female images in women's magazines can be understood as an imaginary reflection of a refined, perfected, "future self" (McCracken 1993). However, as I argue in the remaining part of this analysis, in Krest'ianka these themes are often elaborated vis-àvis the image of the Soviet woman and her relation to fashion.

As Djurja Bartlett (2006) points out, Soviet fashion was mainly an ideological aesthetic project that was used to visualize the ideas of a socialist utopia. At the same time, since Soviet mass production of clothes favored affordability over beauty and creativity, terms such as "dull," "conservative," and "functional" are often attributed to Soviet women's everyday dressing style (Bartlett 2006). An article published in the August 2006 issue of the magazine makes a direct reference to "the question of Soviet style." Here, the journalist Tat'iana Vedeneeva describes her past work attire on Soviet television and reveals that her former employer forbade her to appear in front of the cameras in a dress by a French designer because "an ideological state organization should stay away from fashion" (Denisova 2006d, 85).

Further, although the article describes how Vedeneeva's work in television demanded conservative clothing, she insists that as a person she was far from conservative. To address discrepancies of this sort, one and the same dress could be used endlessly when combined with different jewelry or "unusual scarves" (85). The interview also discusses the change in consumer culture during perestroika and the appearance in 
Soviet stores of foreign consumer items, such as imported fabrics. Around that time, Vedeneeva recalls, she was able to go on a business trip to London, and her description of that experience is striking inasmuch as her representation of consumption practices faithfully encapsulates Soviet attitudes to adornment and plenitude:

At the beginning of the 1980s I visited BBC in London (...). A persnickety journalist there asked, "How many evening gowns do you own?" I honestly counted my dresses and proudly said, "Four!" and she responded, "You know, here stars of your rank have at least forty?" I replied, "We have a different way of life, we work like bees and therefore don't have time for walking around in fine dresses!" (Denisova 2006d, 86)

This example illustrates that, although fifteen years had passed between the end of the Soviet Union and the publication of Vedeneeva's interview, some of Krest'ianka's representations of fashion in the twenty-first century are directly linked to Soviet consumer practices through the genre of reminiscences. Vedeneeva's example indicates that at least for some of Krest'ianka's readers, the memory of the Soviet consumer market still remains fresh. As if to remind the readers of Soviet preferences in production, Vedeneeva is portrayed on the magazine's cover holding a toy tractor in her hand (see Figure 3). For an informed reader, this is an ironic statement regarding the magazine's past tendency to circulate the image of a female tractor driver as an iconic heroine of Soviet collectivization (see Attwood 1999, 94-96).

[Insert Figure 3 here.] 
Alongside this type of blatantly recycled, vivid memories of Soviet consumer culture, Krest'ianka's articles on style are filled with praise for contemporary, international haute couture. Almost without exception, each style interview presents a list of brand names that Russian female celebrities are supposed to use when creating their individual styles. Such is especially the case when the style articles discuss shoes. For example, in answering the question about which shoes she favors, the young actress Nast'ia Tsvetaeva explains, "I think shoes ought to be expensive and of high quality. I like Italian boots the best and also unusual designs from Marithé et François Girbaud and, of course, the legendary Manolo Blahniks" (Denisova 2006a, 112). Judging by the formulation of the question (there is a separate question about "heels and bags") and its many answers, high-heel shoes (as well as bags) function as synonyms for women's individuality. They are the items in which one's personal style culminates. For the actress Ol'ga Kabo, high heels also represent a spiritually uplifting element in a woman's life, as she declares: "I think that when wearing high heels, a woman overcomes her problems" (Denisova 2006b, 109). On the other hand, shoes also represent free and unbounded opportunities to buy and continue buying. For example, Mexican actress Maria Sorte describes her relationship to shoes in the following way:

Shoes are my old hobby! I am constantly adding to my collection of over 450 pairs with new designs from different countries. I have evening shoes and other trendy slip-ons with all kinds of glass and paillette decorations, I have slippers and elegant, comfortable casual shoes. (Denisova 2006e, 109) Even though lists of brand names are a common phenomenon in women's consumer magazines, the way that they are presented in Krest'ianka's style articles may 
be analyzed with reference to the "imaginary consumption" deriving from the Soviet past (Oushakine 2000). In this regard, Serguei Oushakine argues that the early post-Soviet image of abundant consumption was not based as much on goods that were "new" to the post-Soviet consumer, as it was on consuming large quantities of commodities that were treated as status symbols in the Soviet Union. In this situation, "devoid of their symbolic import, goods (...) are 'mindlessly' bought and (...) 'mindlessly' replaced by the same 'mindless' types of goods" (Oushakine 2000, 106).

In a similar manner, Krest'ianka's style articles represent Western goods as an inexhaustible resource for "mindless" post-Soviet consumption. For example, the former figure skater Masha Butyrskaia states, "I adore new things. I might wear some things only three days and get tired of them. Nevertheless, over these three days I get so much pleasure!" (Denisova 2006c, 108). Phrases such as "new things" or "some things" do not provide much information on the nature of the objects purchased, or even on the nature of the pleasure they bring the owner. Things give pleasure simply because they can be endlessly purchased, possessed, and thrown away.

Well-known signifiers of consumer culture (the names of fashion icons and international designers) float through the text as if waiting to be more firmly anchored to the Russian woman portrayed in the center of the "post-Soviet style question." Repeated in almost each interview, this pattern of speech begins to resemble a mantra whose purpose is to take the speaker (and the reader) to a world of unrestrained consumption. Thus, the act of naming well-known brands and fashion designers is a way of attaching post-Soviet female celebrity to the international star cult in the same way that the image of Jacqueline Kennedy is inseparable from her pink Chanel suit or Audrey Hepburn is 
linked to her black evening gown by Givenchy. Krest'ianka thus aims to create the ideal of post-Soviet femininity as "perfected" through ritualistic consumption, which relies on ambiguous images from the past and on undefined ideas about the present and the future (see also Ratilainen 2008a).

\section{Conclusion}

In this article I have argued that images from the past are actively mobilized in the women's magazine Krest'ianka as a powerful discursive tool for the creation of contemporary ideals of Russian womanhood. In my analysis, I identified three discursive frameworks central to the magazine's representation of post-Soviet femininity: naturalized gender differences, Soviet nostalgia, and consumption. My investigation of the representation of gender differences shows that Krest'ianka appropriates an essentialist understanding of gender in order to support the neo-traditional gender ideology prevalent in contemporary Russia. The magazine's articles repeatedly convey gender as something immutable and eternal, stressing the idea of "natural" or "primordial" gender characteristics, according to which one's tasks and duties in society should be determined. I interpret this as Krest'ianka's response to the ongoing discussions on gender roles and gender representations, which the post-Soviet social and economic changes, as well as the changes in the media, have brought to the center of public attention. This gender representation also fits the magazine's brand identity as Krest'ianka strives to represent itself as a "traditional" alternative to Western-format women's magazines.

Krest'ianka's fascination with the past adheres to the symbolic practice of cultural nostalgia prevalent in post-socialist discourse. Cultural nostalgia creates a thematically 
and conceptually coherent framework for combining essentialist perceptions of gender relations with the post-Soviet project of nation building, which has also strived to revive the memory of (Soviet) Russia as a superpower. Viewing Krest'ianka in the analytical framework of cultural nostalgia spotlights the significance of gender and femininity as one of the major categories for understanding national identity building; it also foregrounds the question of reproducibility of certain cultural deep structures, such as the essentialist understanding of gender relations, as an important driving force for social change.

Finally, I have argued that in Krest'ianka Soviet practices of consumption are discussed through reminiscences about material scarcity in Soviet times, as well as through more subtle discursive and stylistic techniques, which simultaneously emphasize the differences and similarities between Soviet and post-Soviet attitudes towards consumption. The themes of fashion and style portray the "new" Russian woman as a post-feminist subject, whose identity is best characterized through her consumption choices. In consequence, this discursive framework negotiates between collective and individualistic values representing Russian womanhood mainly as a personal project, in which Western brands, an individual style, and other symbols and practices of consumer culture play a key role.

In conclusion, we can say that Krest'ianka aims to educate its readers about the adaptability of Soviet gender norms to the changing circumstances of post-Soviet society. By highlighting the many paradoxes and tensions embedded in this project, my analysis helps to shed light on the functioning of globalized media formats in a post-socialist media market. Further, I hope to have pointed out the importance of understanding 
media's gender representations in their historical and cultural contexts. The case of the “old new” women's magazine Krest'ianka signals the many challenges of advancing feminist thought in contemporary Russia.

\section{Notes:}

${ }^{1}$ In Slavic folklore, a domovoi is a house spirit is a mythological creature that protects the home and the family that lives in it (Levkievskaya 1999).

${ }^{2}$ The data include approximately 70 issues and over 100 articles. The printed issues from 2000 through 2011 were read at the Helsinki Slavonic Library; later issues were accessed online at http://journal-off.info/tags/\%CA\%F0\%E5\%F1\%F2\%FC\%FF\%ED\%EA\%E0/ (last accessed June 26, 2014). This article is based, in part, on my doctoral dissertation, Women's Print Media and Consumer Culture in the New Russia (Ratilainen 2013), but presents a revised and updated analysis.

${ }^{3}$ Gill $(2007,149)$ describes post-feminist media culture as consisting of "the entanglement of both feminist and anti-feminist themes" within one text or cultural representation, which reflects the simultaneous celebration of equal rights and essentialist gender discourse. Deprived of notions of political and cultural influence, post-feminist discourse puts an emphasis on individualism, which is manifested through sexuality, professionalism, self-improvement, and hedonistic consumption (Gill 2007; Hermes 2005). Post-feminist media culture stresses the ideas of autonomy and difference by 
combining notions of postmodern identity with those of optimizing and maximizing neoliberal subjectivity (Gill 2007; Salmenniemi and Adamson 2014).

${ }^{4}$ All translations from Krest'ianka are the author's.

5 The transformation has brought about the retrieval of gender polarization on many levels of post-Soviet society. For example, Temkina and Rotkirch $(2002,8-9)$ see this development as a multifaceted reaction to new social and economic conditions. They write, “[i]n post-Soviet Russia men dominate the public and women are elbowed out into the private. [...] Traditional understanding of women's roles in the family and society come out not only as a patriarchal syndrome but as a coping strategy." For more on the “patriarchal renaissance” in post-socialism, see Gapova (2005), Zdravomyslova (2003), and Watson (2000).

${ }^{6}$ Töyry discusses her idea of "negotiable relations" as forming the women's magazines' discourse. She draws on gender contract theory (see Hirdman 1990; Pateman 1988; Temkina and Rotkirch 2002) and argues that women's magazines negotiate different alternatives for female identities and women's roles in a manner that ultimately always coheres with the prevailing gender system of a given society (Töyry 2005, 93-94).

${ }^{7}$ They are published, for example, in the sections Lichnyi uspekh (Individual success) and Vash vykhod (Your way out), which include stories about successful professionals both men and women. 
Acknowledgements: I thank the anonymous reviewers for their valuable feedback. I also thank the issue's editor Nadia Kaneva for guiding me through numerous revisions, and I am deeply grateful to Helena Goscilo for all the help and support that she has kindly provided throughout the process of writing this article.

\section{References}

Attwood, Lynne. 1999. Creating the New Soviet Woman: Women's Magazines as Engineers of Female Identity, 1922-1953. London: Macmillan.

Bartlett, Djurja. 2006. "In Russia, At Last and Forever: The First Seven Years of Russian Vogue." Fashion Theory: The Journal of Dress, Body and Culture 10 (1/2): 175203.

Berg, Mikhail. 2002. "The Status of Literature.” Russian Studies in Literature 38 (2): 640.

Bitov, Andrei. "Nastroenie mesiatsia" [The mood of the month]. Krest'ianka, January 2006, 7.

Borenstein, Eliot. 2008. Overkill: Sex and Violence in Contemporary Russian Popular Culture. Ithaca: Cornell University Press.

Boym, Svetlana. 2001. The Future of Nostalgia. New York: Basic Books.

Cassiday, Julie A., and Emily D. Johnson. 2013. “A Personality Cult for the Post-modern Age: Reading Vladimir Putin's Public Persona.” In Putin as Celebrity and Cultural Icon, edited by Helena Goscilo, 37-64. London: Routledge. 
Dal', Vladimir. 1994. Tolkovyi slovar' zhivogo velikorusskogo iazyka v chetyrekh tomakh [Dictionary of Russian language in four volumes]. Vol. 2. Moscow: Izdatel'skaia gruppa "Progress - Univers."

Denisova, Elena. 2006a. "10 stil'nykh voprosov: Nastia Tsvetaeva” [10 stylish questions: Nastia Tsvetaeva]. Krest'ianka, March, 108-112.

Denisova, Elena. 2006b. "10 stil'nykh voprosov: Ol'ga Kabo" [10 stylish questions: Ol'ga Kabo]. Krest'ianka, June, 106-110.

Denisova, Elena. 2006c. “10 stil'nykh voprosov: Mariia Butyrskaia” [10 stylish questions: Mariia Butyrskaia]. Krest'ianka, July, 106-110.

Denisova, Elena. 2006d. “10 stil'nykh voprosov: Tat'iana Vedeneeva” [10 stylish questions: Tat'iana Vedeneeva]. Krest'ianka, August, 84-89.

Denisova, Elena. 2006e. “10 stil'nykh voprosov: Mariia Sorte” [10 stylish questions: Mariia Sorte]. Krest'ianka, October, 106-110.

Denisova, Elena. 2005. "Schastlivoe kol'tso" [The happy circle]. Krest'ianka, September, $12-17$.

Ferguson, Marjorie. 1983. Forever Feminine: Women's Magazines and the Cult of Femininity. London: Heinemann.

Foucault, Michel. 1972. The Archeology of Knowledge and The Discourse on Language. New York: Pantheon Books.

Gapova, Elena. 2005. "O gendere, natsii i klasse v postkommunizme" [On gender, nation and class in post-communism]. Gendernye issledovaniia [Gender Studies] 13: $101-118$. 
Gill, Rosalind. 2007. "Postfeminist Media Culture: Elements of a Sensibility." European Journal of Cultural Studies 10 (2): 146-166. doi:10.1177/1367549407075898.

Goscilo, Helena. 1996. Dehexing Sex: Russian Womanhood During and After Glasnost. Ann Arbor: University of Michigan Press.

Goscilo, Helena. 1999. "Big-Buck Books: Pulp Fiction in Post-Soviet Russia.” The Harriman Review 12 (2/3): 6-24.

Goscilo, Helena. 2000a. "Introduction: Centrifuge and Fragmentation.” Studies in Twentieth Century Literature 24 (1): 7-17.

Goscilo, Helena. 2000b. "Style and S(t)imulation: Popular Magazines, or the Aestheticization of Postsoviet Russia." Studies in Twentieth Century Literature 24 (1): $15-50$.

Goscilo, Helena, and Vlad Strukov. 2011. "Introduction." In Celebrity and Glamour in Contemporary Russia: Shocking Chic, edited by Helena Goscilo and Vlad Strukov, 1-26. London: Routledge.

Gough-Yates, Anna. 2003. Understanding Women's Magazines: Publishing, Markets and Readerships. London: Routledge.

Gubar, Susan. 1985. “"The Blank Page' and the Issue of Female Creativity.” In The New Feminist Criticism: Essays on Women, Literature, and Theory, edited by Elaine Showalter, 292-313. New York: Pantheon Books.

Gudkov, Lev. 2004. Negativnaia identichnost': Stat'i 1997-2002 godov [Negative identity: Articles 1997-2002]. Moscow: Novoe literaturnoe obozrenie. 
Gudova, M. Iu, and I. D. Rakipova. 2012. Zhenskie gliantsevye zhurnaly: Khronotop voobrazhaemoi povsednevnosti [Women's glossy magazines: The chronotope of the imagined everyday]. Yekateringburg: Ural University Press.

Hemment, Julie. 2007. Empowering Women in Russia: Activism, Aid and NGOs. Bloomington: Indiana University Press.

Hermes, Joke. 2005. Re-reading Popular Culture. Malden: Blackwell.

Hirdman, Yvonne. 1990. "Genussystemet" [The gender system]. In Demokrati och makt $i$ Sverige: maktutredningens huvudrapport [Democracy and power in Sweden:

Final report of the study on power], 73-116. Göteborg: Graphic Systems.

Krest'ianka. 2004. “Seksual'naia revoliutsiia” [Sexual revolution], October, 10, 18-20.

Krest'ianka. 2006 “Zhenshchina in vlast” [Woman and power], August, 8-13.

Krest'ianka. 2007. “Gorditsia stranoi” [To be proud of one's country], March, 7, 14-17.

Latsis, Aleksandra. 2004. “Seksual'naia revoliutsiia: Diskussionnyi klub 'Vperedy planety vsei'” [The sexual revolution: Disccusion club 'Before the whole planet'] Krest'ianka, October, 14-20.

Levkievskaya, Elena. 1999. "Domovoi” [House spirit]. In Slavyanskie Drevnosti: Etnollingvisticheskii Slovar' [Slavic antiquity: An ethno-linguistic dictionary], edited by N. I. Tolstoy, vol. 2, 120-124. Accessed October 11, 2014. http://ecdejavu.ru/g-2/Goblin.html.

Litovskaia, Mariia. 2008. “Obraz dostoinogo budushchego v postsovetskikh izdaniiakh dlia devushek-podrostkov" [The image of a good future in post-Soviet publications for adolescent girls]. In Obraz dostoinoi zhizni v sovremennykh rossiiskikh SMI [The image of good life in contemporary Russian media], edited 
by Maria Litovskaia, Arja Rosenholm, Irinia Savkina, and Elena Trubina, 270285. Yekateringburg: Ural University Press.

Lovell, Stephen. 2000. Russian Reading Revolution: Print Culture in Soviet and PostSoviet Eras. London: Macmillan.

McCracken, Ellen. 1993. Decoding Women's Magazines: From Mademoiselle to Ms. London: Macmillan.

Mel'nikova, Anastasiia. 2014. “Anastasiia Mel'nikova: O muzhchinakh i zhenshchinakh” [Anastasia Mel'nikova: About men and women]. Krest'ianka, January, 8.

Menzel, Birgit. 2005. "Writing, Reading and Selling Literature 1986-2004.” In Reading For Entertainment in Contemporary Russia: Post-Soviet Popular Literature in Historical Perspective, edited by Birgit Menzel and Stephen Lovell, 39-57. Munchen: Sagner.

Menzel, Birgit. 2008. "Russian Discourse on Glamour.” Kultura. Russian Cultural Review 6: 4-8. www.kultura-rus.unibremen.de/kultura_dokumente/ausgaben/englisch/kultura_6_2008_EN.pdf.

Morris, Jeremy. 2005. “The Empire Strikes Back: Projections of National Identity in Contemporary Russian Advertising." The Russian Review 64 (4): 642-660.

Oushakine, Serguei Alex. 2000. "The Quantity of Style: Imaginary Consumption in the New Russia." Theory, Culture \& Society 17 (5): 97-120.

Oushakine, Serguei Alex. 2007. “'We're nostalgic but we're not crazy': Retrofitting the Past in Russia." The Russian Review 66 (3): 451-482.

Pateman, Carol. 1988. The Sexual Contract. Palo Alto, CA: Stanford University Press. 
Platt, Kevin M. F. 2009. “The Post-Soviet Is Over: On Reading the Ruins.” Republics of Letters: A Journal of the Study of Knowledge, Politics, and the Arts 1 (1): 1-26.

Ratilainen, Saara. 2008a. “'Den nya ryska skönheten': damtidningen Krestjankas ‘Tio stilfrågor”' ['The new Russian beauty': The women's magazine Krest'ianka’s ‘Ten questions of style']. Nordisk Øst forum 22 (3/4): 313-335.

Ratilainen, Saara. 2008b. 'Nostal'giia 'Krest'ianki': istoriia i pamiat' v tekstakh zhenskogo zhurnala" [Nostalgia 'Krest'ianki': History and memory in the texts of a women's magazine]. In Obraz dostoinoi zhizni v sovremennykh rossiiskikh SMI [The image of good life in contemporary Russian media], edited by Maria Litovskaia, Arja Rosenholm, Irina Savkina, and Elena Trubina, 238-256. Yekateringburg: Ural University Press.

Ratilainen, Saara. 2010. “'Family - That's an Opera': Creativity and Family Representation in Russian Women's Magazine Krest'ianka." In Russian Mass Media and Changing Values, edited by Arja Rosenholm, Kaarle Nordenstreng, and Elena Trubina, 157-174. London: Routledge.

Ratilainen, Saara. "Women's Print Media and Consumer Culture in the New Russia." PhD diss., University of Tampere, 2013.

Rivkin-Fish, Michelle. 2006. 'From 'Demographic Crisis' to 'Dying Nation' - The Politics of Language and Reproduction in Russia." In Gender and National Identity in Twentieth-Century Russian Culture, edited by Helena Goscilo and Andrea Lanoux, 151-74. Dekalb, IL: Northern Illinois University Press.

Rosenholm, Arja, and Irina Savkina. 2010. “'We Must all Give Birth: That's an Order”: The Russian Mass Media Commenting on V.V. Putin's Address.” In Russian 
Mass Media and Changing Values, edited by Arja Rosenholm, Kaarle Nordenstreng, and Elena Trubina, 79-101. London: Routledge.

Rotkirch, Anna, Anna Temkina, and Elena Zdravomyslova. 2007. "Who Helps the Degraded Housewife? Comments on Vladimir Putin's Demographic Speech.” European Journal of Women's Studies 14 (4): 349-357. doi: $10.1177 / 1350506807081884$.

Salmenniemi, Suvi. 2014.. "Feminismi, naisliike ja tasa-arvon paradoksit" [Feminism, women's movements and the paradoxes of equality]. In Naisia Venäjän kulttuurihistoriassa [Women in Russian cultural history], edited by Arja Rosenholm, Suvi Salmenniemi, and Marja Sorvari. Helsinki: Gaudeamus. 290315.

Salmenniemi, Suvi, and Maria Adamson. 2014. "New Heroines of Labour: Domesticating Post-feminism and Neoliberal Capitalism in Russia." Sociology doi: $10.1177 / 0038038513516830$.

Shokhina, Tat'iana. 2001. "Neravnyi brak" [Unequal marriage]. Krest'ianka, August, 810.

Shokhina, Tat'iana. 2004a. "Uroki peniia” [Singing lessons]. Krest'ianka, January, 6-11.

Shokhina, Tat'iana. 2004b. "Khudozhestvennyi domostroi" [Artistic patriarchy]. Krest'ianka, February, 6-11.

Shokhina, Tat'iana. 2004c. "Vozvrashchenie" [Return]. Krest'ianka, September, 6-13.

Shokhina, Tat'iana. 2005. "Pered Bogom i liud'mi” [Before God and people] Krest'ianka, February, 10-15. 
Stoichita, Victor I. 2008. The Pygmalion Effect: From Ovid to Hitchcock. Chicago: University of Chicago Press.

Temkina, Anna, and Anna Rotkirch. 2002. "Sovetskie gendernye kontrakty i ikh transformatsiia v sovremennoi Rossii" [Soviet gender contracts and their transformation in contemporary Russia]. Sotsiologicheskie issledovaniia 11: 4-13.

Töyry, Maija. 2005. Varhaiset naistenlehdet ja naisten elämän ristiriidat: Neuvotteluja lukijasopimuksesta [Early women's magazines and the conflicts of women's lives: Negotiations on the reader contract]. Helsinki: Helsinki University Press.

Vartanova, Elena, and Sergei Smirnov. 2010. “Contemporary Structure of the Russian Media Industry." In Russian Mass Media and Changing Values, edited by Arja Rosenholm, Kaarle Nordenstreng, and Elena Trubina, 21-40. London: Routledge.

Watson, Peggy. 2000. "Rethinking Transition: Globalism, Gender and Class." International Feminist Journal of Politics 2 (2): 185-213.

Winship, Janet. 1987. Inside Women's Magazines. London: Pandora.

Zdravomyslova, Ol'ga. 2003. Sem 'ia i obshchestvo: gendernoe izmerenie rossiiskoi transformatsii [Family and society: The gender dimension of the Russian transformation]. Moscow: URSS.

\section{Biography:}

Saara Ratilainen $(\mathrm{PhD})$ is a postdoctoral fellow and teacher at the University of Tampere (Finland), School of Language, Translation and Literary Studies. The title of her doctoral dissertation (defended in 2013) is Women's Print Media and Consumer Culture in the New Russia. Her areas of expertise include Russian media and culture, gender and class 
in Russia, representations of travel and tourism, consumption studies, and theories of culture. Her articles have been published in journals and edited volumes. 